\title{
Spatial Correspondence Between R-C adherin Expression Domains and Retinal Ganglion Cell Axons in Developing Zebrafish
}

\author{
Q. LIU, ${ }^{1 *}$ J .A. MARRS, ${ }^{2}$ AND P.A. RAYMOND ${ }^{1}$ \\ ${ }^{1}$ Department of Anatomy and Cell Biology, University of Michigan, \\ Ann Arbor, Michigan 48109 \\ 2Department of Medicine, I ndiana U niversity Medical Center, I ndianapolis, I ndiana 46202
}

\begin{abstract}
Mechanisms underlying axonal pathfinding have been investigated for decades, and numerous molecules have been shown to play roles in this process, including members of the cadherin family of cell adhesion molecules. We showed in the companion paper that a member of the cadherin family (zebrafish R-cadherin) is expressed in retinal ganglion cells, and in presumptive visual structures in zebrafish brain, during periods when the axons were actively extending toward their targets. The present study extends the earlier work by using 1,1'-dioctadecyl-3,3,3',3', tetramethylindocarbocyanine perchlorate (Dil) anterograde tracing techniques to label retinal ganglion cell axons combined with R-cadherin in situ hybridization to explicitly examine the association of retinal axons and brain regions expressing R-cadherin message. We found that in zebrafish embryos at 46-54 hours postfertilization, Dil-labeled retinal axons were closely associated with cells expressing R-cadherin message in the hypothalamus, the pretectum, and the anterolateral optic tectum. These results demonstrate that R-cadherin is appropriately distributed to play a role in regulating development of the zebrafish visual system, and in particular, pathfinding and synaptogenesis of retinal ganglion cell axons. J . Comp. Neurol . 410:290-302, 1999. @ 1999 Wiley-Liss, Inc.
\end{abstract}

Indexing terms: zebrafish embryo; development; cell adhesion molecules; retinofugal projections; axonal pathfinding

During development of the vertebrate visual system, retinal ganglion cells extend their axons along defined paths to reach their targets in the brain (Sperry, 1963). The molecular mechanisms underlying this phenomenon have been investigated for years (Bonhoeffer and Gierer, 1984; Trisler and Collins, 1987; Walter et al., 1987; O'Rourkeand F raser, 1990). One of the ol dest and the most influential theories to account for selective axonal outgrowth is the chemoaffinity hypothesis, which states that retinal ganglion cells and their targets acquire corresponding molecular markers early on in development, and the establishment of appropriate connections between the retinal ganglion cells and their targets depends on the correct matching of molecules present on pre and postsynaptic neurons (Sperry, 1963; Fuj isawa et al., 1982). M ol ecuIar candidates include the recently identified E ph-related receptor tyrosine kinases (RTKs) and various families of adhesion molecules. The E ph-related RTKs are expressed in a spatially restricted pattern in zebrafish brain and play a role in the development of the zebrafish central nervous system, particularly the retinotectal system ( $\mathrm{Xu}$ et al., 1996; Cooke et al., 1997; Drescher et al., 1997). Adhesion molecules implicated in guiding growing axons include members of the immunoglobulin superfamily, which have been shown to play important roles in growth cone el ongation, axon fasciculation, and axonal guidance (Dodd and J essell, 1988; Bixby and Harris, 1991; Brümmendorf et al., 1993; Bastmeyer et al., 1995; Stoeckli and Landmesser, 1995), and the cadherin superfamily, some members of which are also expressed in the vertebrate brain in a spatiotemporally restricted manner (Takeichi, 1990; Takei-

Grant sponsor: NIH; Grant number: EY 11365; Grant number: EY04318; Grant number: NRSA EY06892.

*Correspondence to: Q. Liu, Department of Anatomy and Cell Biology, 4610 Medical Science II, University of Michigan, Ann Arbor, MI 48109. E-mail: qliu@umich.edu

Received 29J uly 1998; Revised 12 February 1999; Accepted 26 February 1999 
chi et al., 1990; Redies et al., 1992, 1993; Arndt and Redies, 1996; F ranklin and Sargent, 1996).

Classic cadherins (e.g., N-, R-, E-cadherins) are known to bind tissues together through strong homophilic interactions (Takeichi, 1990, 1995). More recently, it was suggested that cadherins play a pivotal role in the formation and stabilization of pre- and postsynaptic connections in vertebrate central nervous system (CNS; Yamagata et al., 1995; Uchida et al., 1996; Fannon and Colman, 1996; I noue and Sanes, 1997). Functional analyses using either cadherin antibodies or a genetic approach (expression of dominant-negative mutant cadherin) have demonstrated that these calcium-dependent homophilic adhesion molecules play important roles in axonal outgrowth, including that of retinal axons (Matsunaga et al., 1988a,b; Neugebauer et al., 1988; Tomaselli et al., 1988; Bixby and Zhang, 1990; Drazba and Lemmon, 1990; Paradies and Grunwald, 1993; Redies and Takeichi, 1993; Williams et al., 1994; Riehl et al., 1996; Stone and Sakaguchi, 1996). Cadherins havealso been implicated in regionalization of brain nuclei and neural circuits (Redies et al., 1992, 1993; Matsunami and Takeichi, 1995; Arndt and Redies, 1996; Redies and Takeichi, 1996; Redies, 1995, 1997).

We recently isolated partial CDNAs of a zebrafish cadherin (see the companion paper, Liu et al., 1999), which shares extensive sequence homology to chicken (I nuzuka et al., 1991), mouse (Hutton et al., 1993; Matsunami et al., 1993), and human R-cadherin (Tanihara et al., 1994). Zebrafish R-cadherin message was detected in the retina and in nearly all of the retinal recipient regions of the adult zebrafish brain (Liu et al., 1999). In embryonic zebrafish, R-cadherin was found in both retinal ganglion cells and in brain regions that were presumptive terminal sites of the retinal axons during periods of outgrowth and synaptogenesis of retinal ganglion cell axons. Based on these results, we proposed that R-cadherin might play a role in the pathfinding and synaptogenesis of the retinal ganglion cell axons in zebrafish (Liu et al., 1999). If $\mathrm{R}$-cadherin plays a role in the formation of specific visual circuits, then there must be a close association between retinal axons and cells expressing R-cadherin along their pathway and/or in their postsynaptic targets. To test this hypothesis, we utilized $1,1^{\prime}$-dioctadecyl-3,3,3',3', tetramethylindocarbocyanine perchlorate (Dil)-labeling of the retinal ganglion cell axons combined with in situ hybridization with R-cadherin probes to examinethespatial relationship between retinal ganglion cell axons and cells expressing R-cadherin message in embryos at 46-54 hours postfertilization, a period when retinal ganglion cell axons are actively migrating towards, and arborizing in, their brain targets.

\section{MATERIALS AND METHODS Animals}

Zebrafish embryos were collected from our outbred colony and maintained according to standard procedures (Westerfield, 1996). After approximately 12 hours of development, the embryos were transferred to tanks that contained 1-phenyl-2-thiourea (PTU; $0.2 \mathrm{mM}$; Sigma; St. Louis, MO) to block the development of melanin pigmentation (Westerfield, 1996). Ages of the embryos are given as hours postfertilization (hpf). All animal-related procedures were conducted in accordance with the National Institute of Health Guide for the Care and U se of Labora- tory Animals and wereapproved by the University Committee on Use and Care of Animals.

\section{Tissue preparation}

Embryos at 46-54 hpf were anesthetized in $0.02 \%$ methane tricaine sulfonate (Sigma), and fixed for 1 hour in phosphate-buffered, $4 \%$ paraformaldehyde (pH 7.4). The embryos were then rinsed in $0.1 \mathrm{M}$ phosphate buffer $(\mathrm{pH}$ 7.4) and processed for double-labeling.

\section{Dil-labeling of the retinal axons}

Dil (Molecular Probes, Eugene, OR) dissolved in N,Ndimethylformamide ( $2.5 \mathrm{mg} / \mathrm{ml})$ was pressure-injected intraocularly into fixed embryos (Burrill and Easter, 1994). The embryos were placed in $4 \%$ paraformaldehyde, and the Dil was allowed to transport overnight at $4^{\circ} \mathrm{C}$. The fluorescent Dil signal was then photoconverted to a permanent, black-brown reaction product by photoexcitation of the dye in the presence of diaminobenzidene (DAB; 20 mg/25 ml; Sigma) (von Bartheld et al., 1990; Singleton and Casagrande, 1996). One or both eyes were removed before the photoconversion to facilitate the process. The embryos were dehydrated in $70 \%$ then $100 \%$ methanol, stored in $100 \%$ methanol at $-20^{\circ} \mathrm{C}$ for approximately 1 week, and then processed for wholemount in situ hybridization with zebrafish R-cadherin cRNA probes (see below).

\section{Probe synthesis.}

The cDNA insert (1,982 bp) of clone 9, containing both coding and 3'-untranslated zebrafish R-cadherin sequences (see the companion paper, Liu et al., 1999) was used as a template to generate CRNA probes for in situ hybridization. After linearization of the template DNA with restriction enzymes, either $\mathrm{Notl}$ (for the sense probe) or Xhol (for the antisense probe), approximately $1 \mu \mathrm{g}$ of the template DNA was transcribed from T7 and T3 polymerases for generating sense and antisense digoxigeninlabeled RNA probes, respectively, by using the Genius System (Boehringer Mannheim, Indianapolis, IN). The specificity of the antisense probe was examined previously (Liu et al., 1999).

\section{Wholemount in situ hybridization}

Procedures for wholemount in situ hybridization were modified from J owett et al. (1996). Briefly, embryos were rehydrated through a descending concentration of methanol, followed by proteinase $\mathrm{K}$ (Boehringer Mannheim) treatment (10 $\mu \mathrm{g} / \mathrm{ml}, 15$ minutes). The embryos were then fixed in 4\% paraformaldehyde for 20 minutes, washed in phosphate-buffered saline containing $0.1 \%$ Tween 20 (PBST, pH 7.4). After 2 hours of prehybridization, the embryos were moved into a fresh hybridization solution containing the cRNA probe $(1 \mu \mathrm{g} / \mathrm{ml})$ and hybridized overnight at $56^{\circ} \mathrm{C}$. The next day, the embryos were washed in $2 \times$ SSC ( $0.3 \mathrm{M}$ sodium chloride, $0.03 \mathrm{M}$ sodium citrate) containing $0.1 \%$ Tween 20 (SSCT), followed by $50 \%$ formamide in $2 \times \mathrm{SSCT}$ at $60^{\circ} \mathrm{C}$. They were then washed twice (10 minutes each) in $2 \times$ SSCT at $60^{\circ} \mathrm{C}$ (low stringency condition), and twice (30 minutes each) in $0.2 \times$ SSCT at $70^{\circ} \mathrm{C}$ (high stringency condition). F or immunocytochemical detection of cRNA probes, anti-digoxigenin $\mathrm{Fab}$ fragment antibodies conjugated to alkaline phosphatase were used with the substrate 4-nitroblue tetrazolium 


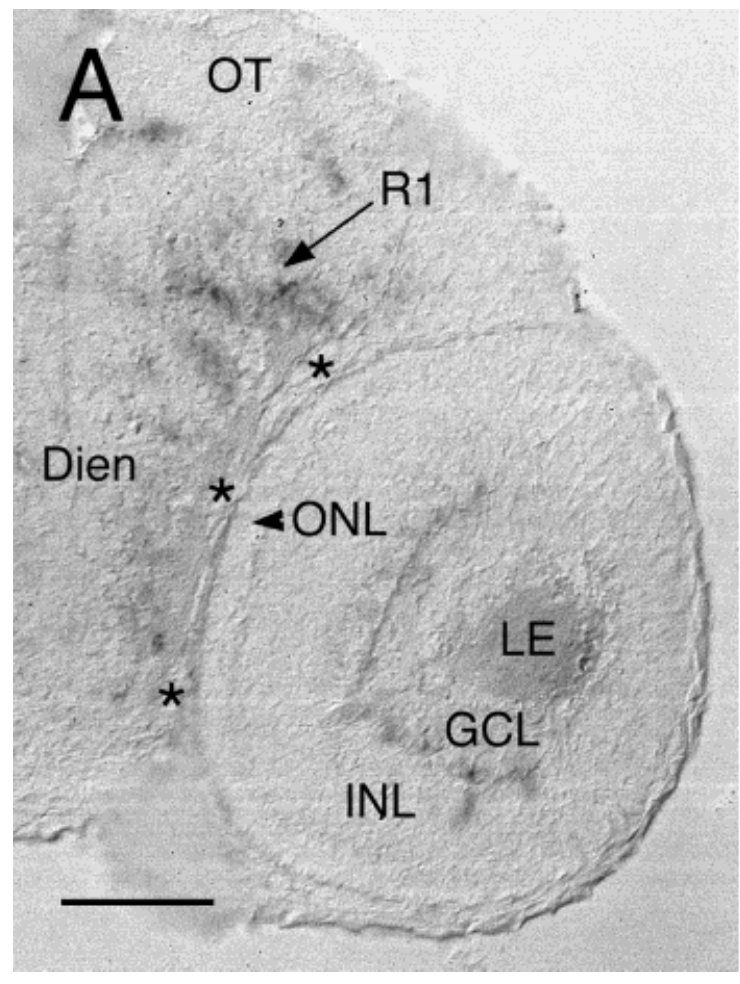

Fig. 1. R-cadherin message in the retina, diencephalon, and pretectum of developing zebrafish. A: Transverse section of an embryo at 52 hours postfertilization (hpf). Dorsal is at the top and medial is to the left. In the retina, R-cadherin expression was located in the ganglion cell layer (GCL) and the innermost portion of the inner nuclear layer (INL). In the brain, clusters of cells expressing R-cadherin are in close proximity to axonal tracts (asterisks) in the lateral thalamus and the pretectum (R1). B: Wholemount zebrafish embryo at $46 \mathrm{hpf}$ (lateral

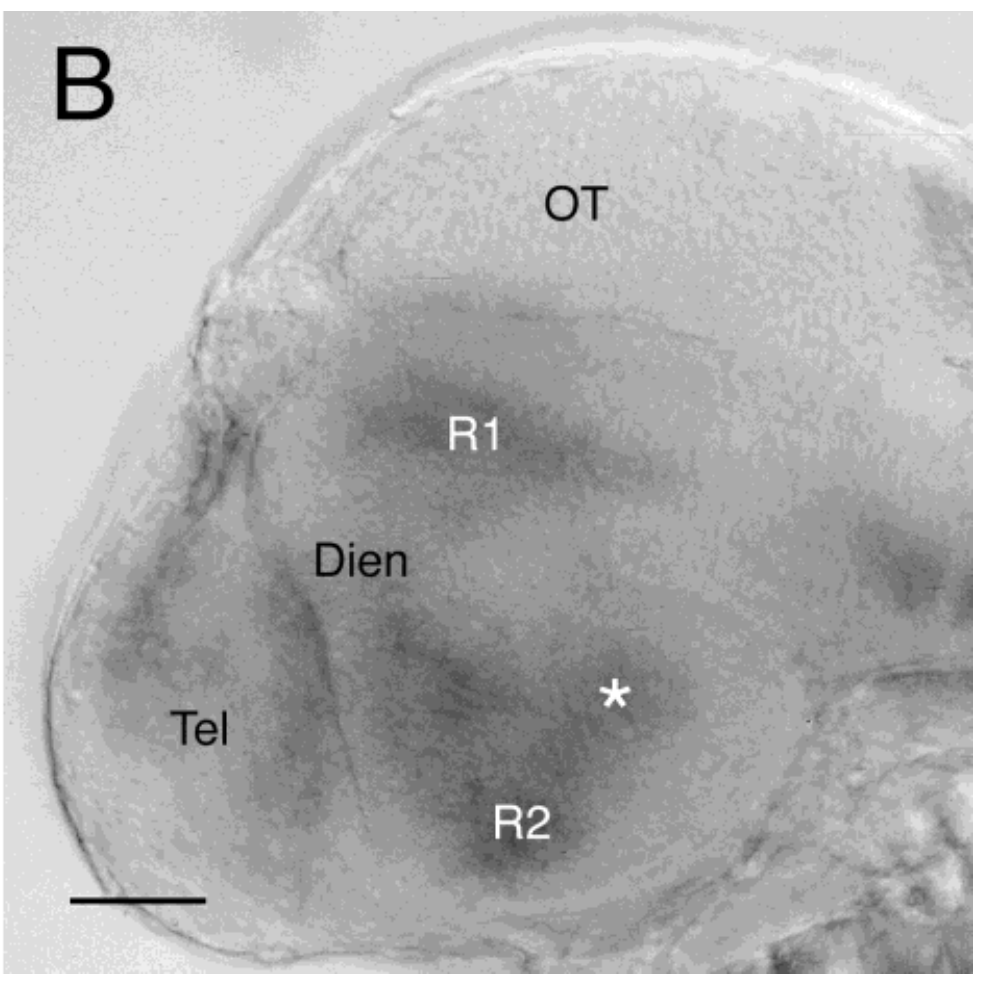

view) showing labeling pattern of R-cadherin message in the pretectum (R1) and hypothalamus (R2). Dorsal is at the top and anterior is to the left. Patches of labeled cells were al so seen between R 1 and R 2 and in the telencephalon. The asterisk indicates the lens in the eye on the other side of the brain, which is also R-cadherin-positive. Dien, diencephalon; LE, Iens; ONL, outer nuclear layer; OT, optic tectum; Tel, telencephalon. Scale bars $=50 \mu \mathrm{m}$. chloride (NBT) and 5-bromo-4-chloro-3-indolyl phosphate (BCIP; Boehringer Mannheim). To check the specificity of the signal, the sense probe was applied to a separate set of whole embryos.

Following in situ hybridization, the embryos werecleared in glycerin and mounted onto slides. After photography the embryos were washed in phosphate buffer, embedded, and cryosectioned as described (Barthel and Raymond, 1990) and finally mounted onto slides.

\section{Anti-acetylated tubulin labeling.}

Some embryos at 36, 46, and 54 hpf were stained with anti-acetylated tubulin antibody (Sigma) after the in situ hybridization to determine the locations of cells that expressed R-cadherin message in relation to major axonal tracts (Chitnis and Kuwada, 1990; Wilson et al., 1990). Wholemount in situ hybridization was performed as described above. The embryos were then fixed for 20 minutes in $4 \%$ paraformaldehyde, washed in PBST, and processed for immunocytochemistry with the tubulin antibody. Secondary antibody was biotinylated anti-mouse IgG (Vector Labs, Burlingame, Ca) which was detected with avidinconjugated horseradish peroxidase, visualized with DAB (Vector Labs). The methods for wholemount immunocytochemistry were essentially as described by Westerfield (1996).

Photomicrographs were digitized, processed, and formatted with Photoshop (Adobe, Mountain View, CA), and printed with a dye sublimation printer (Kodak, XLS 8600 PS, Eastman Kodak, Rochester, NY).

\section{RE SULTS \\ $\mathbf{R}$-cadherin expression in the visual system}

The expression pattern of R-cadherin message in the visual system of developing zebrafish embryos was described in the companion paper (Liu et al., 1999). In the retina of embryos between 46-54 hours hpf, cells expressing R-cadherin were located in the retinal ganglion cell layer and the inner portion of the inner nuclear layer (Fig. $1 \mathrm{~A})$. In the early embryonic brain, R-cadherin message was detected in a pretectal area designated R1 (Liu et al., 1999) and in a hypothalamic area called R2 (Fig. 1B). Patches of label ed cells were also found between these two regions in the lateral thalamus. Adjacent to these R-cadherin-positive cells were fiber tracts, some of which we knew werelikely to be retinal ganglion cell axons based on earlier descriptions of the location of optic fibers in the early fiber tracts of zebrafish brain (Chitnis and Kuwada, 1990; Wilson et al., 1990; Burrill and Easter, 1994; Fig. 1A).

The zebrafish embryonic brain is demarcated by relatively few major axonal tracts at the stages we examined (Chitnis and Kuwada, 1990; Wilson et al., 1990; Ross et al., 
1992). Double-labeling with the R-cadherin cRNA probe and acetylated tubulin antibody revealed the relationship between regions expressing $\mathrm{R}$-cadherin message and some of the major axonal tracts. The neural tube bends during morphogenesis; here we adopt the system of nomenclature (Puelles et al., 1987; Ross et al., 1992) in which the anterior-posterior axis is defined anteriorly by the tract of postoptic commissure (TPOC) and posteriorly by the medial longitudinal fasciculus. At 36 hpf (Fig. 2A), only a few cells in the pretectal area R1 expressed R-cadherin, and they were located along and immediately posterior to the lower one-third of the tract of the posterior commissure (TPC). In the hypothalamus, R-cadherin was expressed in cells in an area called R2, located at the junction of the TPOC and the supraoptic tract (SOT). In embryos at 46 and 54 hpf, R1 had expanded mainly in the anterodorsal direction, and cells expressing R-cadherin were found along almost the entire length of the TPC (Fig. 2B, C). At $46 \mathrm{hpf}$, the majority of R-cadherin-expressing cells in R1 were found immediately caudal to the TPC (Fig. 2B), whereas in embryos at $54 \mathrm{hpf}$, the number of R-cadherinpositive cells located in R1 immediately anterior to the TPC had increased, and the number of cells expressing $\mathrm{R}$-cadherin on both sides of the TPC was approximately equal (Fig. 2C).

In the hypothalamus, the size of $\mathrm{R} 2$ remained relatively constant between 36, 46, and 54 hpf (approximately 50-60 $\mu \mathrm{m}$ across the longest axis), as did the relative labeling intensity. However, the position of $\mathrm{R} 2$ relative to the TPOC changed. In embryos at $36 \mathrm{hpf}$, the main portion of R2 was dorsal and medial to the TPOC (Fig. 2A); at $46 \mathrm{hpf}$, the main portion of R2 was medial and slightly ventral to the TPOC (Fig. 2B); at $54 \mathrm{hpf}, \mathrm{R} 2$ was located ventral to the TPOC (Fig. 2C). Because of the close proximity between the TPOC and retinal axons in this area (Wilson et al., 1990; Burrill and Easter, 1995), it was likely that the spatial relationship between retinal axons and R2 also changed over this interval. This inference was confirmed in the next set of experiments.

In addition to the cells expressing $\mathrm{R}$-cadherin message in R1 and R2, smaller clusters of R-cadherin-positive cells were seen in diencephalic regions between the SOT and the TPC, especially at $54 \mathrm{hpf}$ (Fig. 2C).

\section{Dil-labeling of retinal ganglion cell axons at early stages}

Based on the results from previous studies of the retinofugal projections in zebrafish embryos (Stuermer, 1988; Burrill and Easter, 1994, 1995), and our previous study of the expression pattern of R-cadherin in the diencephalon and pretectum (Liu et al., 1999), R1 and R2 appeared to be located along the pathway of retinal ganglion cell axons. In order to examine the spatial relationship between cells that expressed R-cadherin message in $\mathrm{R} 1$ and $\mathrm{R} 2$ and growing retinal ganglion cell axons, welabeled the optic axons of embryos (46-54 hpf) with Dil, then processed these embryos for in situ hybridization using the zebrafish R-cadherin cRNA probe.

Intraocular injection of Dil in zebrafish embryos at 46-54 hpf consistently labeled retinal ganglion cell axons projecting to the brain. In both wholemounts and in sections prepared from wholemounts, dark brown retinal axons were easily recognized against either a light (no hybridization signal) or a purple/blue (R-cadherin hybridization signal) background. Viewed from the lateral side of a wholemount embryo, the labeled retinal axons emerged
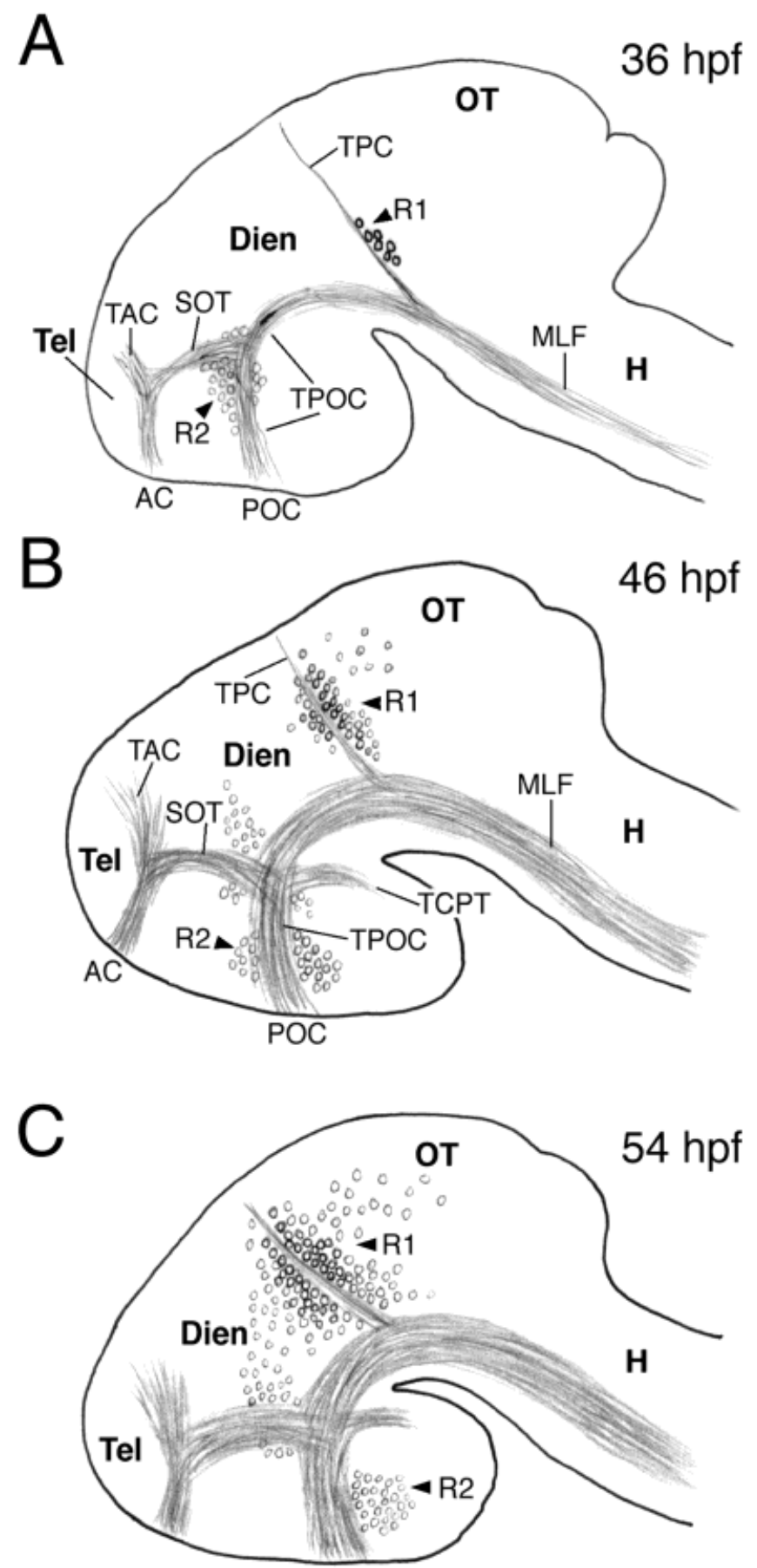

Fig. 2. A-C: Composite sketches based on camera lucida drawings of wholemount embryos (double-labeled with R-cadherin cRNA probe and acetylated tubulin antibody) showing the relationship between cells expressing R-cadherin (areas R1 and R2) and some of the major axonal tracts. Regions containing cells expressing R-cadherin in the diencephal on and pretectum are indicated by clusters of small circles. R-cadherin expression in the telencephalon and in caudal brain regions is omitted. The thinner tracts (the dorsoventral diencephalic tract, the tract of the anterior commissure, and the tract of the habenular commissure) were not well labeled in our samples, so they were omitted from these sketches. AC, anterior commissure; $\mathrm{H}$, hindbrain; MLF, medial longitudinal fasciculus; POC, postoptic commissure; SOT, supraoptic tract; TAC, tract of the anterior commissure; TCPT, tract of the commissure of the posterior tuberculum; TPC, tract of the posterior commissure; TPOC, tract of the postoptic commissure. Other abbreviations as in Figure 1. 

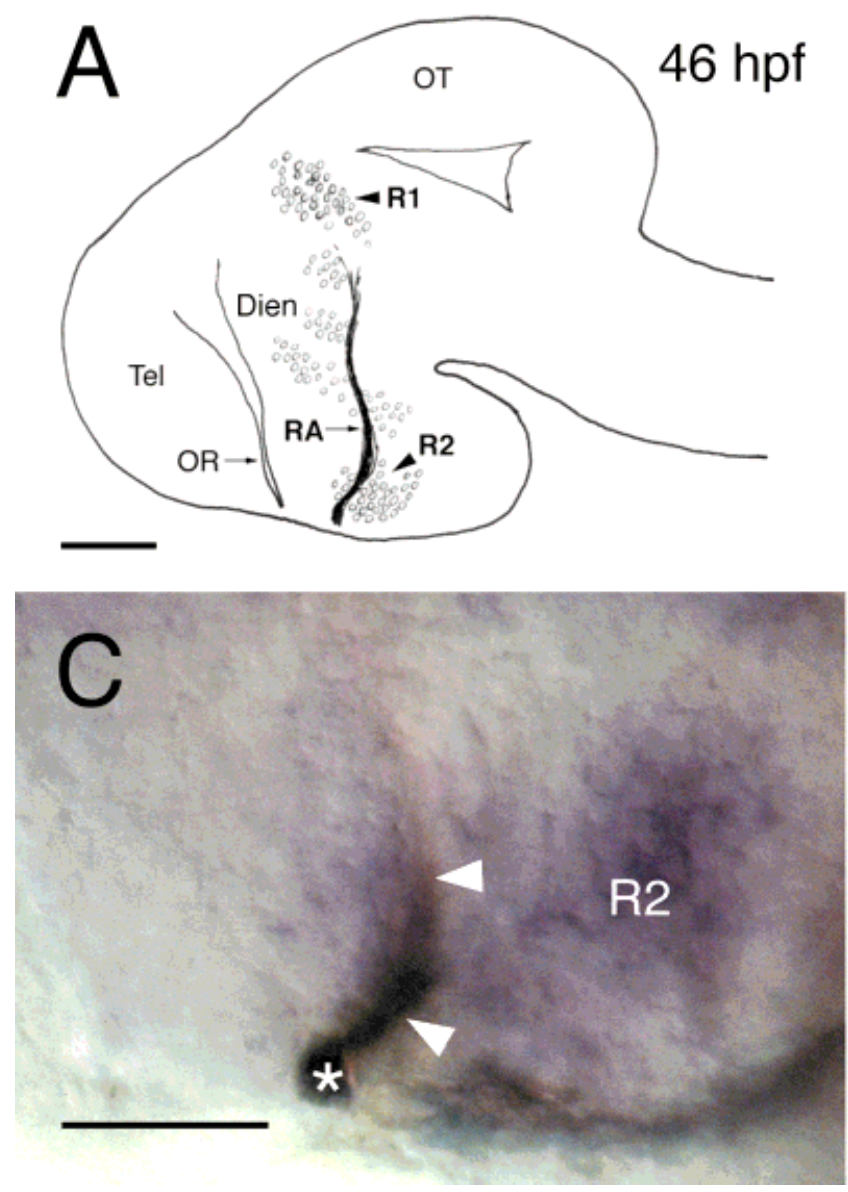

Fig. 3. Relationship between cells expressing R-cadherin message in R2 and 1, $1^{\prime}$-dioctadecyl-3,3,3' $3^{\prime}$, tetramethylindocarbocyanine perchlorate (Dil)-labeled retinal axons. A: Camera lucida drawing of a wholemount embryo at 46 hours postfertilization (hpf) showing the trajectory of Dil-labeled retinal axons (RA) in relation to patches of cells (open circles) expressing R-cadherin message in the diencephal on (Dien) and the pretectum (R1). B: Lateral view of the same wholemount embryo focusing on the hypothalamic area. Dil-labeled retinal

from the optic chiasm and formed a tight fascicle that projected posterodorsally towards the optic tectum (Figs. $3,5)$. In embryos at $46-48 \mathrm{hpf}$, Dil-labeled retinal axons (Fig. 3) were not as numerous as they were in embryos at later stages (Figs. 6, 7). The fascicles formed by the earliest axons (Fig. 3) were thin, and their trajectory was less direct compared to later embryos (Figs. 6, 7).

\section{Relationship between $\mathrm{R} 2$ and early retinal axons}

From a lateral view, Dil-labeled retinal axons in wholemount embryos at 46-48 hpf appeared to pass directly over the large cluster of R-cadherin-positive cells in the hypothalamus (R2; Fig. 3A, B). Closer examination of this area revealed that the bulk of R2 was located immediately ventral to the optic chiasm, and medial and ventral to the initial segment of the optictract, just past the optic chiasm (Fig. 3C, D). The majority of cells in R2 that expressed high levels of R-cadherin message were caudal to the optic tract, a few were immediately medial to the tract, and very few were dorsal to the tract.

Transverse sections of this area prepared from the whol emount embryos confirmed these observations. Many
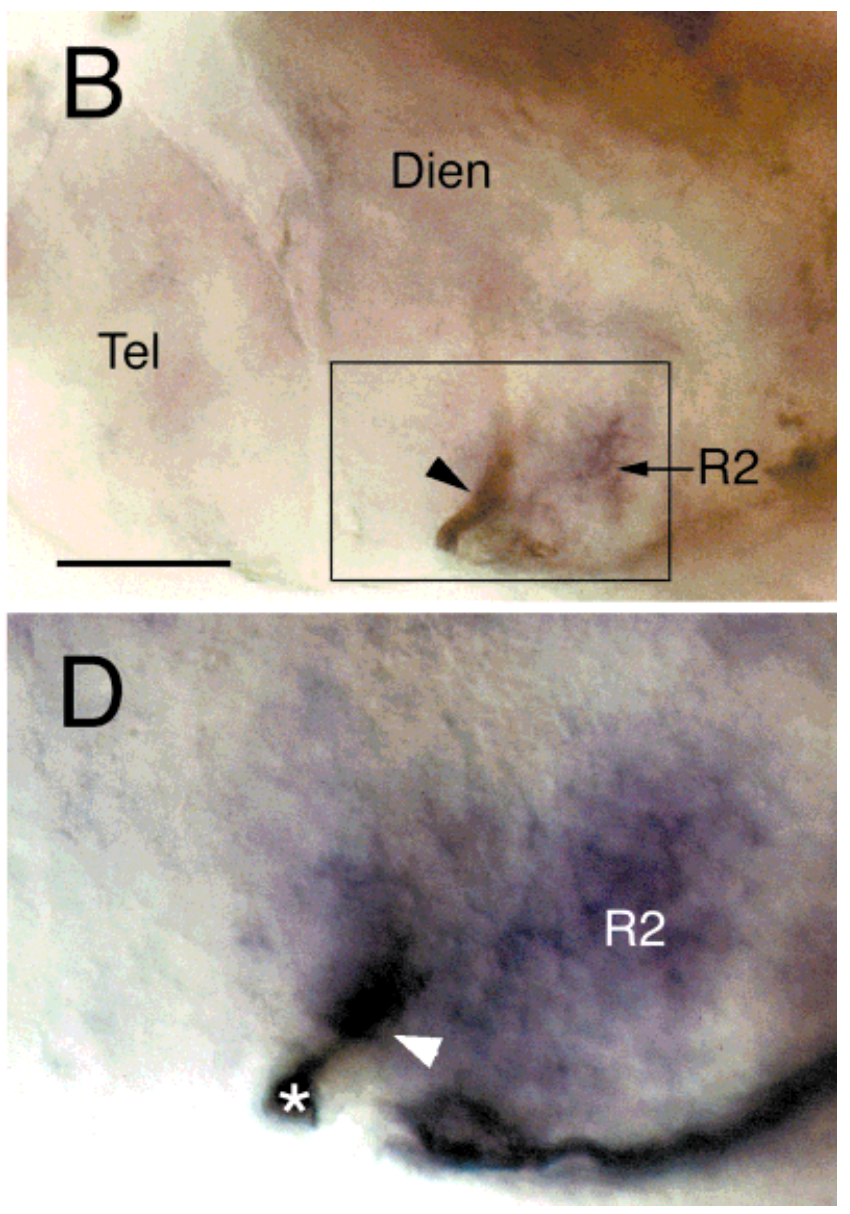

axons (arrowhead) cross over R-cadherin-positive cells in R2. C and D: Higher magnifications of the boxed area in B, at different planes of focus but with the same magnification. The Dil-labeled retinal axons (white arrowheads) were in close proximity to a group of cells that expressed high levels of R-cadherin message in R2 (purple). Asterisks in $C$ and $D$ indicate the optic chiasm. OR, optic recess. Other abbreviations as in Figure 1. Scale bars $=50 \mu \mathrm{m}$ for A and B; $25 \mu \mathrm{m}$ for C and D.

cells that expressed R-cadherin message in R2 were located in the vicinity of the optic chiasm and the initial portion of the optic tracts (Fig. 4). Burrill and Easter (1994) have described ten terminal fields in which retinal axons arborize in the embryonic zebrafish brain, which they designated AF 1-AF 10. The location of the cells in R2 suggests that it corresponds to the future AF 1 of Burrill and Easter (1994), which is located ventrocaudal to the optic chiasm, and which forms later, at about $60 \mathrm{hpf}$.

\section{Relationship between cells expressing R-cadherin and later retinal axons}

In older embryos (52-54 hpf), there was a change in the spatial relationship between the Dil-labeled optic tract and cells expressing R-cadherin in R2. Although still located ventral to the optic tract, R2 was separated from it by a gap (approximately $25-30 \mu \mathrm{m}$ ) in which little or no R-cadherin message was detected (Fig. 5). Dil injections at these stages also resulted in more labeled retinal axons (Figs. 6, 7). Retinal axons at this stage had projected farther dorsally into the diencephalon; they maintained a tight fascicle through the first half of their trajectory and then fanned out as they approached the pretectum (Fig. 6). 

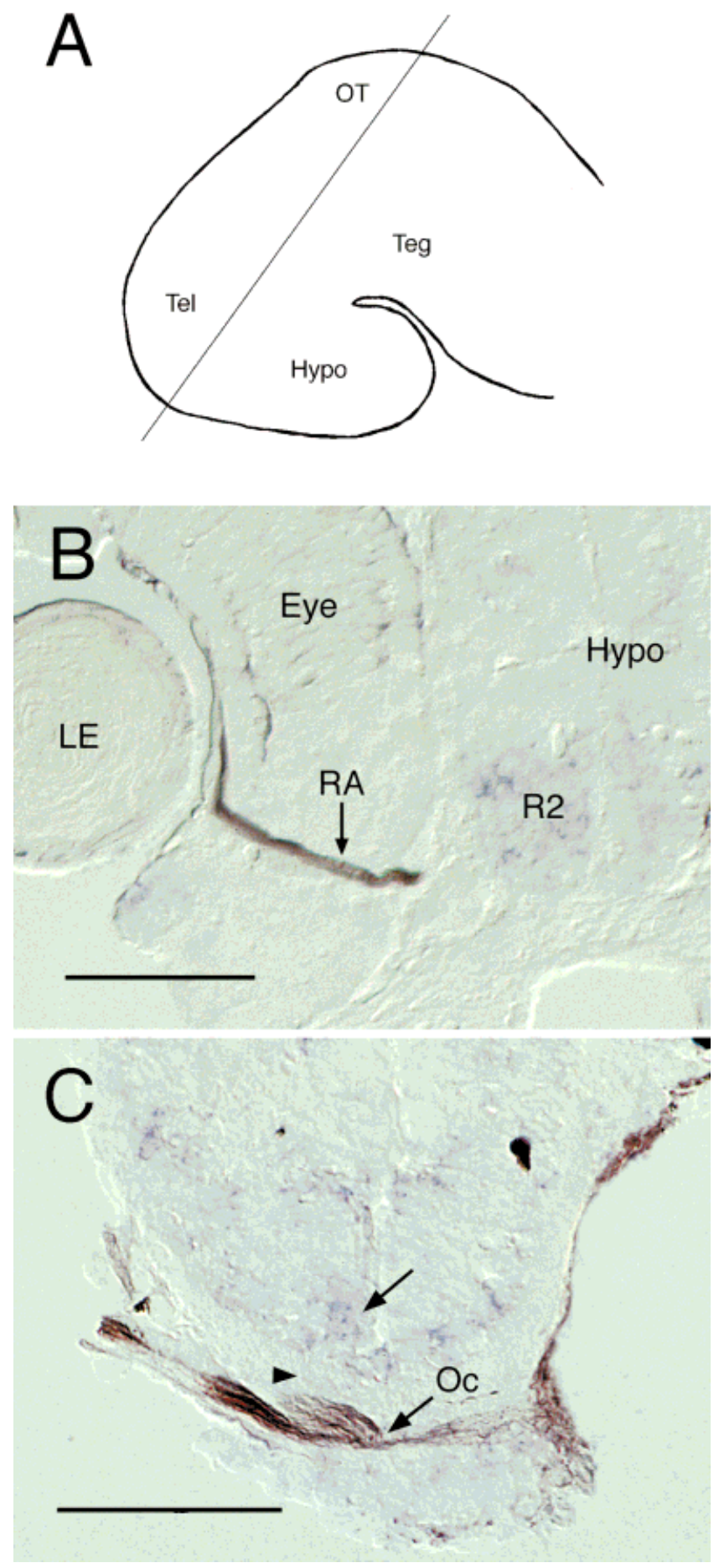

Fig. 4. Transverse sections of embryos at 46-48 hours postfertilization (hpf) illustrating 1, 1'-dioctadecyl-3,3,3',3', tetramethylindocarbocyanine perchlorate (Dil)-labeled retinal axons in relation to cells expressing R-cadherin message in R2. A: Schematic drawing of the brain (lateral view) showing the plane of sectioning. B: Dil-labeled retinal axons (RA) exit the eye, and project toward a large cluster of cells in the ventral hypothalamus that express R-cadherin message (R2). C: At the level of optic chiasm (Oc; a few sections caudal to B) retinal axons were located in the vicinity of R-cadherin-positive cells (arrow) in R2. Both optic tracts were labeled. Some weakly labeled axons (arrowheads) could be followed under high magnification with Nomarski optics as they left the optic tract and approached R2. Hypo, hypothalamus; Teg, tegmentum. Other abbreviations as in Figure 1. Scale bars $=50 \mu \mathrm{m}$.
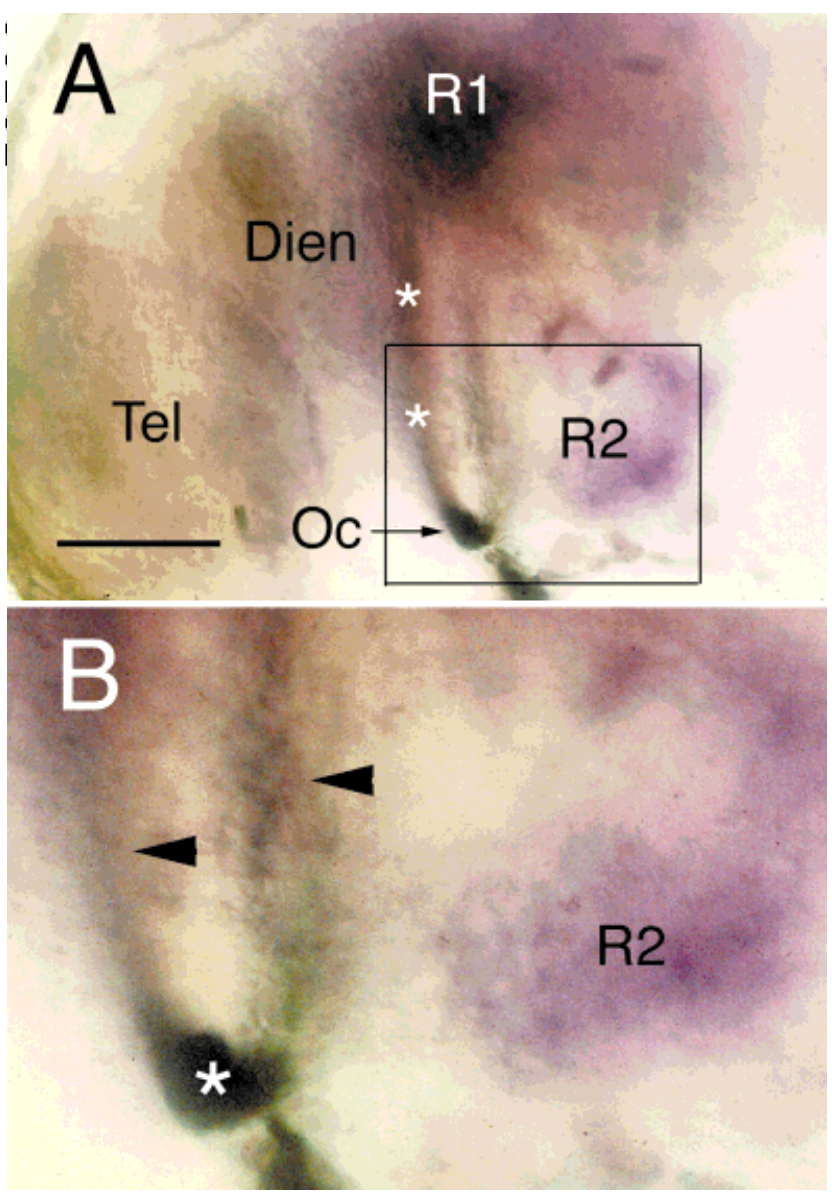

Fig. 5. A: Lateral view of the forebrain area of an embryo (wholemount, 52 hours postfertilization, hpf) showing the spatial relationship between $1,1^{\prime}$-dioctadecyl-3,3,3',3', tetramethylindocarbocyanine perchlorate (Dil)-label ed retinal axons (asterisks) and cells expressing R-cadherin message in R2 (purple). Anterior is to the left and dorsal is at the top. B: Higher magnification of the boxed area in A. Due to the transparency of the embryo, both of the optic tracts can be seen (arrowheads). Notice a region between the retinal axons and R2 devoid of R-cadherin expression. Abbreviations as in Figures 1 and 4. Scale bar $=50 \mu \mathrm{m}$ for $\mathrm{A} ; 20 \mu \mathrm{m}$ for $\mathrm{B}$.

Dil-labeled retinal axons became less tightly fasciculated as they approached the pretectum, and they projected directly toward and then into the cluster of cells in R1 (Figs. 6, 7). The width of the fan of retinal axons approximately corresponded to the anteroposterior extent of the R1 cluster (Fig. 6C, D). Although the majority of Dil-labeled retinal axons, upon reaching the pretectum, projected toward R1, a small number of axons turned anterodorsally in the pretectum (Figs. 6D, 7) and projected toward a small cluster of cells that expressed moderate levels of R-cadherin message (Figs. 6C, D; 7B, C). These R-cadherin-positive cells appeared to be located in the anterior portion of embryonic retinal terminal field AF-9 (Burrill and Easter, 1994).

Examination of sections prepared from $52-54 \mathrm{hpf}$ wholemount embryos revealed a thick bundle of Dil-labeled retinal axons that projected dorsally, just beneath the pial surface toward the optic tectum (F ig. 8). U pon reaching the level of R1, many axons appeared to defasciculate and turn mediodorsally toward clusters of cells in R 1 that expressed high levels of R-cadherin message (Fig. 8B, C). Some of 


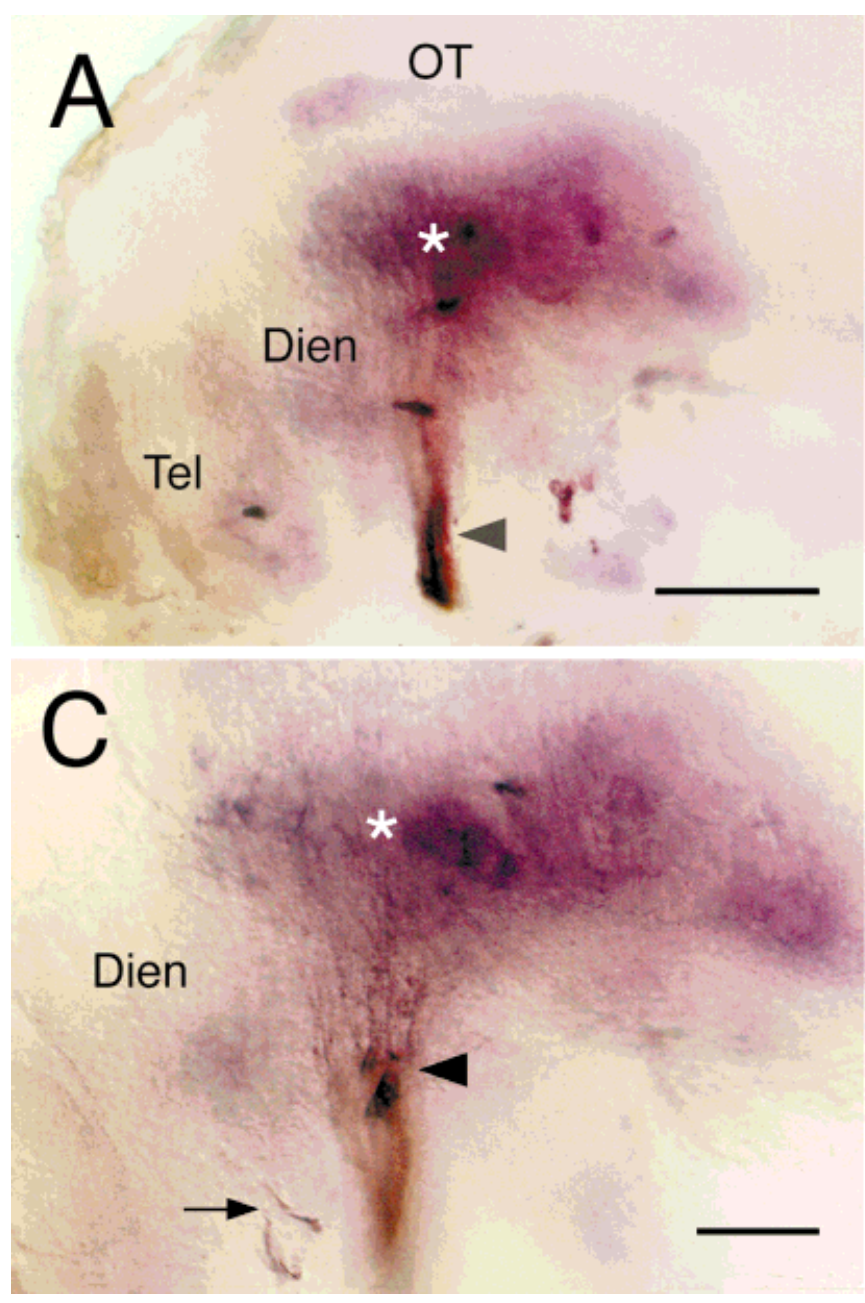

Fig. 6. A: Lateral view of a wholemount zebrafish embryo brain (52 hours postfertilization, hpf). The arrowhead points to a fascicle of retinal axons labeled with $1,1^{\prime}$-dioctadecyl-3,3,3',3', tetramethylindocarbocyanine perchlorate (Dil). The axons project posteriorly and dorsally toward R1, a group of cells in the pretectum that express high levels of R-cadherin message (asterisk). The plane of focus is on the anteroventral portion of the optic tract to show its tight fasciculation.

these R-cadherin-positive cells (Fig. 8A-C) appeared to be located in a retinal axon terminal field called AF-7 (Burrill and Easter, 1994). Many retinal axons in the optic tract did not turn mediodorsally at the pretectal region, but instead followed the contour of the lateral surface of the brain. Other R-cadherin-positive cells were located nearby, and some of these cells seemed to be contacted by retinal axons (Figs. 8D, 9A, B).

Clusters of cells expressing R-cadherin in the lateral thalamus were also found in close proximity to Dil-labeled retinal axons (Fig. 8C). These cells may correspond to other future retinal terminal fields, such as AF - 4 and AF -5 (Burrill and Easter, 1994). Along the retinal pathway from the optic chiasm to the pretectum, we did not observe any labeled retinal axons that left the optic tract and projected toward R-cadherin-negative areas.

In summary, the majority of Dil-labeled retinal axons formed a tight fascicle and projected directly from the optic chiasm toward R1, but some axons left the main optic tract and projected to other regions of the thalamus and pretec-
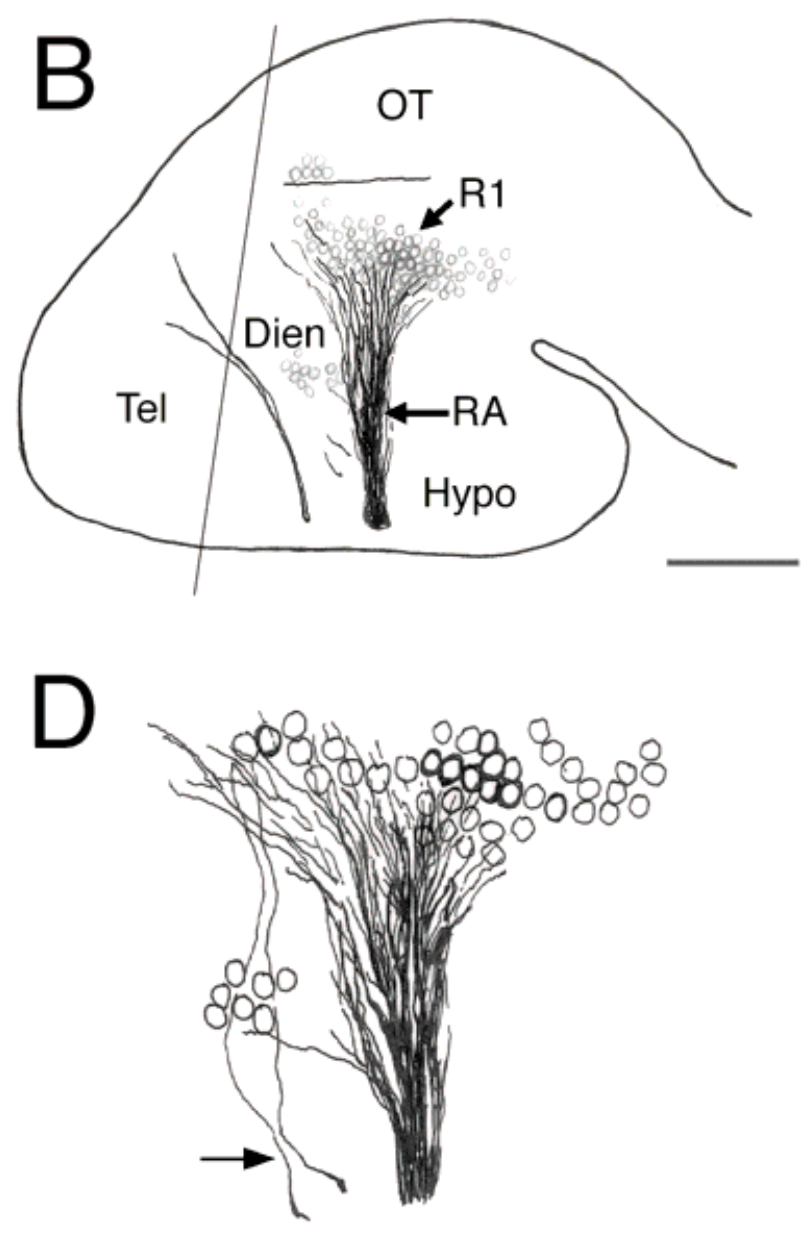

B: Camera lucida drawing of A. C is a higher magnification of the diencephal on and the pretectum. D: Camera lucida drawing of $\mathbf{C}$. The arrow (C and D) points to a few retinal axons that were not bundled together with the majority of the axons. Open circles represent cells that expressed high levels of R-cadherin message, and darker circles represent cells that were most intensely labeled. Abbreviations as in Figures 1 and 4 . Scale bars $=50 \mu \mathrm{m}$ for $A$ and $B ; 25 \mu \mathrm{m}$ for $C$ and $D$.

tum, often toward smaller patches of cells that expressed R-cadherin.

\section{Retinal axons that entered the optic tectum were not always associated with cells expressing R-cadherin}

At the stages westudied, retinal ganglion cell axons had just reached the anterior portion of the optic tectum (Stuermer, 1988; Burrill and Easter, 1994). Cells expressing R-cadherin message in the optic tectum of embryos at 46-54 hpf were detected only in the anterior half of the tectum (Liu et al., 1999). However, there were few R-cadherin-positive tectal cells, and those tectal cells expressing high levels of R-cadherin message were typically adjacent to R1. Examination of sections prepared from double-labeled wholemounts showed that in anterior tectal regions immediately dorsal to $\mathrm{R} 1$, Dil-labeled retinal axons were in close proximity to R-cadherin-positive tectal cells (Fig. 9A, B). However, in more dorsal tectal 
areas (farther from R1), tectal cells that expressed $\mathrm{R}$-cadherin were more frequently observed in deeper tectal layers, and a close spatial relationship between Dillabeled retinal axons and cells that expressed R-cadherin message was no longer observed (Fig. 9C).

\section{DISCUSSION \\ R-cadherin in developing zebrafish visual system}

In the embryonic zebrafish retina, onset of expression of R-cadherin (see the companion paper, Liu et al., 1999)
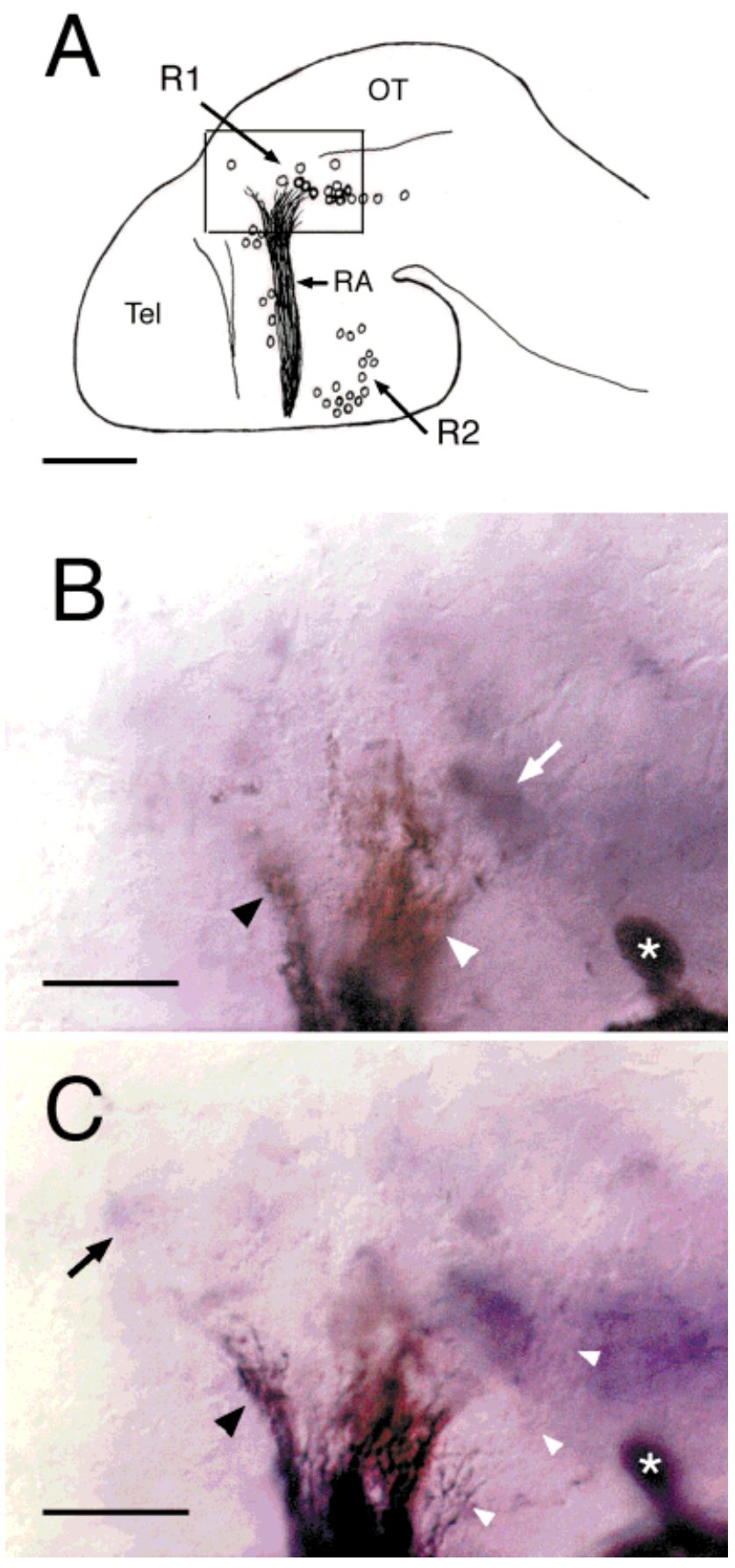

corresponds closely to the stage when retinal ganglion cells begin to differentiate and extend their axons (Burrill and Easter, 1994, 1995). As the number of differentiating ganglion cells increases, more cells express R-cadherin in the retinal ganglion cell layer, and the levels of expression increase (Liu et al., 1999). In the embryonic brain, the developmental profile of R-cadherin expression also correlates closely with the known trajectory and timing of retinal ganglion cell axon outgrowth. Clusters of cells in the hypothalamus, the thalamus, the pretectum, and the optic tectum begin to express R-cadherin message just prior to the arrival of the optic axons, and expression is greatly increased during the period when the retinal axons are arborizing within their targets (48-80 hpf; Stuermer, 1988; Burrill and Easter, 1994; Liu et al., 1999). These observations suggest that R-cadherin molecules may be involved in pathfinding and synaptogenesis of retinal ganglion cell axons.

The current study extends our previous findings on the distribution of cells expressing R-cadherin message in the diencephalon and pretectum of embryos at 36-54 hpf, and it examines in detail their relationship to retinal axons with double-labeling techniques that use acetylated tubulin antibody or Dil-labeling of retinal axons, combined with the R-cadherin CRNA probe. The results of these double-labeling studies provide evidence that two of the major clusters of cells described previously (Liu et al., 1999) that expressed R-cadherin message (R1 and R2) were indeed located al ong the pathway of retinal ganglion cell axons. We further demonstrate that retinal axons often seemed to contact R-cadherin-positive cells, suggesting that these clusters of cells correspond to some of the terminal fields of retinal axons described by Burrill and Easter (1994). In the optic tectum, R-cadherin-positive cells adjacent to $\mathrm{R} 1$ were also located next to retinal axons.

\section{Retinal axons in the optic tract may follow a pathway defined by R-cadherin}

Development of the retinofugal projections in embryonic zebrafish has been well characterized (Stuermer, 1988; Burrill and Easter, 1994). The results of our anterogradelabeling of retinal axons are consistent with these earlier findings. We chose the stages of development between 46 and $54 \mathrm{hpf}$ to examine the relationship between growing retinal axons and the pattern of R-cadherin expression for several reasons. First, in embryos younger than $46 \mathrm{hpf}$,

Fig. 7. 1,1'-dioctadecyl-3,3,3',3', tetramethylindocarbocyanine perchlorate (Dil)-labeled retinal axons and cells expressing R-cadherin message in the pretectum of an embryo at 52 hours postfertilization (hpf). Anterior is to the left and dorsal is at the top. A: Camera lucida drawing (lateral view) showing a thick bundle of retinal axons (RA) projecting toward the optic tectum (OT). Small open circles represent cells expressing high levels of R-cadherin message. $\mathbf{B}$ and $\mathbf{C}$ are higher magnifications of the boxed area in A, with different planes of focus. Most retinal axons (white arrowheads) projected toward cells expressing high levels of R-cadherin message (white arrow in B). The three smaller white arrowheads in $\mathrm{C}$ point to some retinal axons that were not well labeled with Dil, but were visible under Nomarski optics. A small bundle of retinal axons (black arrowheads) deviated from the major bundle and projected anterodorsally toward a small cluster of cells (black arrow in $C$; only one of these cells was drawn in A) expressing moderate levels of R-cadherin. Asterisks in B and C represent a displaced piece of skin. Abbreviations as in Figure 1. Scale bars $=50 \mu \mathrm{m}$ for $\mathrm{A} ; 20 \mu \mathrm{m}$ for $B$ and $C$. 


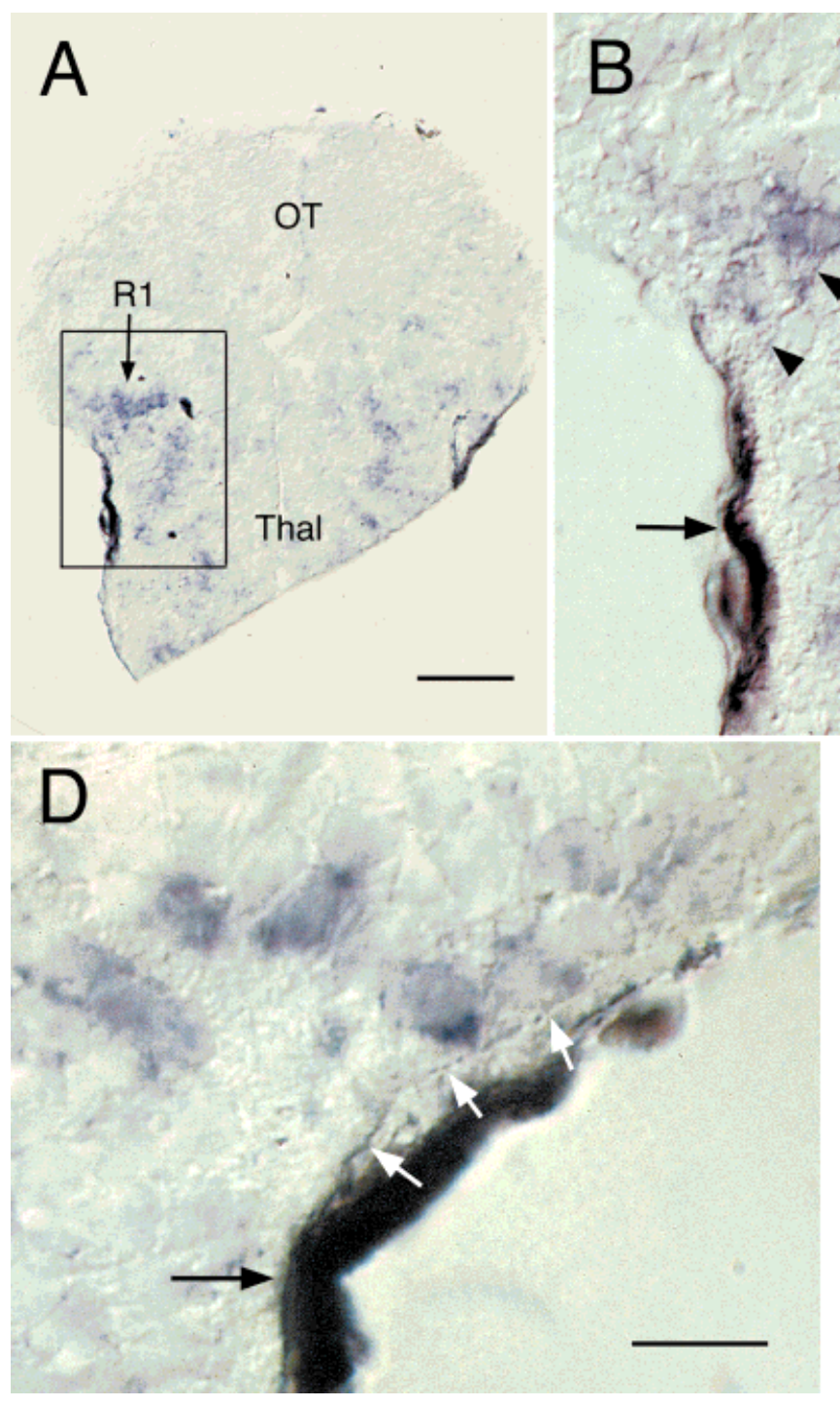

Fig. 8. Frontal sections prepared from whol emount embryos (52-54 hours postfertilization, hpf) double-labeled with 1,1'-dioctadecyl$3,3,3^{\prime}, 3^{\prime}$, tetramethylindocarbocyanine perchlorate (Dil) and R-cadherin CRNA probe. Dorsal is at the top. A: Dil-labeled retinal axons (black) in close proximity to clusters of R-cadherin-positive cells in the pretectal area (R1). B: Higher magnification of the boxed area in A. $C$ and $D$ are higher magnifications of corresponding regions from

adjacent sections. Black arrows point to the thick bundle of Dil-labeled retinal axons, and arrowheads (in B and C) and white arrows (in D) indicate retinal axons that appeared to make contact with R-cadherinpositive cells. The larger arrowhead in $C$ points to a cluster of R-cadherin-positive cells in the lateral thalamus (Thal) along the pathway of retinal axons. Abbreviations as in Figure 1. Scale bars $=50$ $\mu \mathrm{m}$ for $\mathrm{A} ; 25 \mu \mathrm{m}$ for $\mathrm{B}$ and $\mathrm{C} ; 10 \mu \mathrm{m}$ for $\mathrm{D}$.

only a few retinal axons had reached the brain, which would decrease our chances of labeling sufficient number of axons for analysis. Second, the hybridization signal for $\mathrm{R}$-cadherin message in brains of embryos younger than 46 hpf was relatively weak, and the signal usually became weaker after Dil transport and photoconversion. Third, in embryos older than $54 \mathrm{hpf}, \mathrm{R}$-cadherin had spread more widely throughout the brain (Liu et al., 1999), and most retinal axons had al ready reached their targets (Stuermer, 1988; Burrill and Easter, 1994).

Labeling of retinal axons with Dil allowed us to chart their outgrowth in relation to changing patterns of Rcadherin expression. Outgrowing retinal axons approached the brain on the ventral surface of the hypothalamus. We found that R2, a major site of R-cadherin expression, is directly apposed to the pial surface along which the earliest retinal axons grew (at 46-48 hpf). However, once the early wave of axons had moved beyond this region (at 52-54 hpf), cells in the vicinity of the optic chiasm no longer expressed R-cadherin, and R-cadherin expression was observed more ventrally. There are at least two possible explanations for the shift in position of $\mathrm{R} 2$ relative to the optic chiasm. Cells adjacent to the chiasm may have ceased to express R-cadherin message, wher eas cells immediately ventral to R2 may have begun to express the message. Another possibility is that the cells expressing R-cadherin may have been displaced ventrally due to intercalation of new, R-cadherin-negative cells in this 


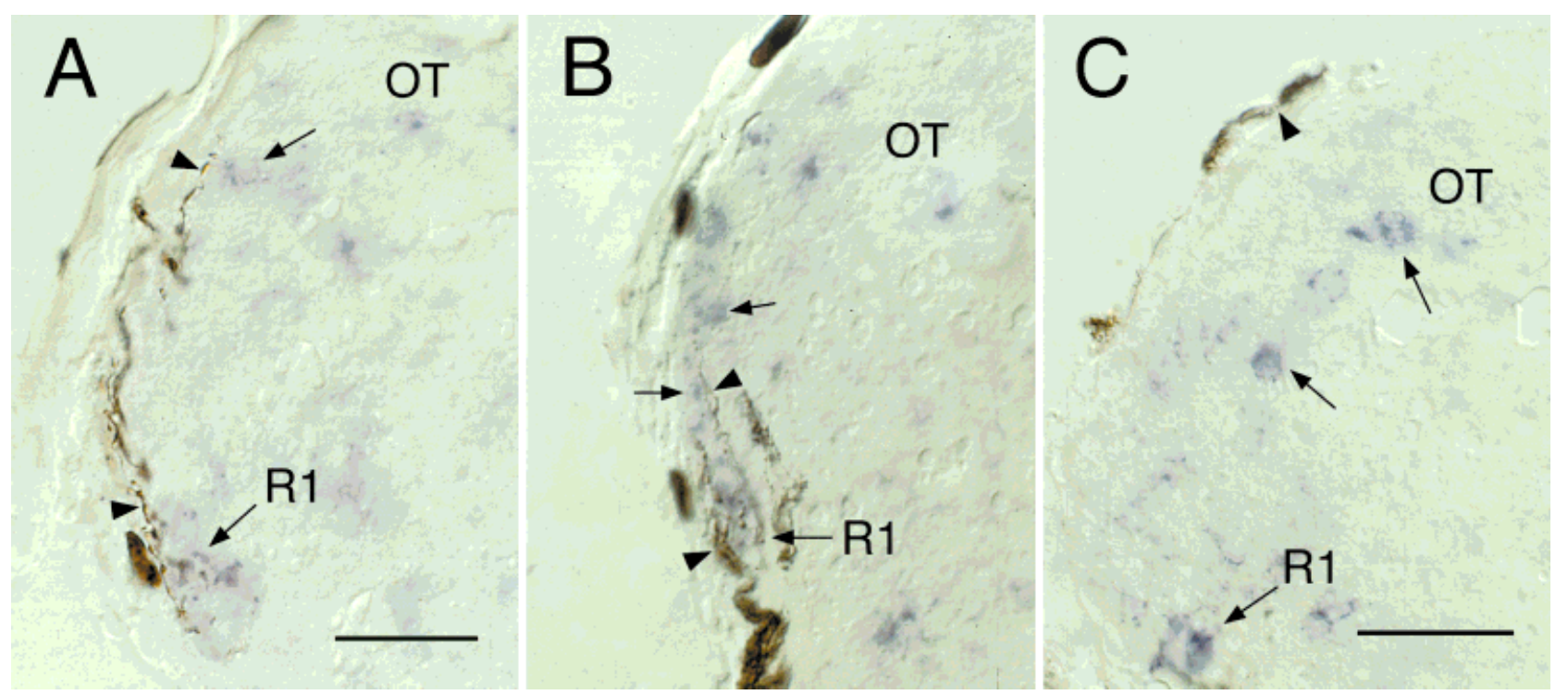

Fig. 9. Frontal sections through the optic tectum (OT) prepared from wholemount embryos double-labeled with 1,1'-dioctadecyl$3,3,3^{\prime}, 3^{\prime}$, tetramethylindocarbocyanine perchlorate (Dil) and $\mathrm{R}$-cadherin CRNA probe (52-54 hours postfertilization, hpf). Dorsal is at the top, lateral is to the left. Note the cells expressing R-cadherin message (arrows) next to Dil-labeled retinal axons (arrowheads) in the anterolateral portion of the tectum immediately adjacent to R1 (A and B). C: In more dorsal tectal regions, R-cadherin expression (arrows) was found in deeper tectal layers, but not in the immediate vicinity of Dil-labeled retinal axons (arrowhead). Scale bars $=20 \mu \mathrm{m}$. area. Additional experiments are required to distinguish between these possibilities.

Burrill and Easter (1994) showed that in embryonic zebrafish brain, retinal axons arborize in 10 terminal fields (AF 1-AF 10). There are also ten retinorecipient targets in the adult brain, but because of theimmaturity of the embryonic brain at the time when the terminal fields were established, these authors could not determine in all cases which of the embryonic fields corresponded to each of the known adult retinal targets. Two exceptions were AF 1 , which is the suprachiasmatic nucleus, and AF 10, which is the optic tectum. A small number of retinal axons terminate in the presumptive suprachiasmatic nucleus (AF1) located dorsocaudal to the optic chiasm (Burrill and Easter, 1994), and this terminal field, which is established at $60 \mathrm{hpf}$, is likely to be either within R2 or overlap with R2. By 52-54 hpf, the earliest retinal axons had reached the level of the pretectum and tectum. I $n$ the diencephal on and pretectum of the embryonic brain, a large group of cells expressed high levels of R-cadherin message (R1), and the earliest retinal ganglion cell axons to reach this level were located in close proximity to cells that expressed R-cadherin message.

As the optic tract passed through the lateral thalamus and pretectum, someaxons deviated from the main bundle of the optic tract and projected toward smaller clusters of cells expressing R-cadherin. Based on their location, these targets were identified as AF 4, AF 5, AF 7, and AF 9 of Burrill and Easter (1994). Some of these terminal fields had not yet formed by the time we conducted our Dillabeling, but they are later (at 60-66 hpf) found to be clustered in the pretectum (Burrill and Easter, 1994), where R1 is located. In summary, these observations, together with earlier studies (Burrill and E aster; 1994; Liu et al., 1999), suggest that R-cadherin is expressed by groups of cells that later become targets of arborizing retinal axons, and that R-cadherin expression is maintained in the retinorecipient nuclei in the adult brain.

In a recent review, Redies (1997) speculates that if homophilic adhesion mediated by cadherin molecules were to play a role in the formation of neural circuits and target recognition, then outgrowing neurites or growth cones should alter their growth or branching behavior when they reach brain areas that express the same cadherin at high levels, or the neurites may be induced to defasciculate when they encounter a target that expresses a high amount of that cadherin. The results of the present study provide some supporting evidence for this hypothesis. We showed that some retinal axons changed their behavior as they approached areas that expressed high levels of R-cadherin message. For example, some retinal axons turned toward R-cadherin-expressing cells in the thalamus and pretectum (Figs. 6-9), and upon reaching $R 1$, many retinal axons defasciculated and projected toward cells that expressed high levels of R-cadherin (Figs. 6, 7). These observations, together with our description of R-cadherin expression in developing and adult zebrafish (see the companion paper, Liu et al., 1999), suggest a potential role for R-cadherin-mediated adhesive interactions in axonal guidance, especially as related to pathfinding and target recognition by the earliest retinal axons.

We have shown in this study that R-cadherin message is strongly expressed by retinal ganglion cells during stages of active axonal outgrowth (Liu et al., 1999), and by brain cells which retinal fibers appear to contact. We have recently developed a polyclonal antibody to a synthetic peptide that represents an epitope in the EC4 domain of the zebrafish R-cadherin, and our preliminary results using this antibody confirmed that R-cadherin protein was expressed on outgrowing retinal axons, and in regions of the brain where R-cadherin message was localized (Liu, 
Marrs and Raymond, unpublished observations). We are currently using this antibody to examine the functional roles of R-cadherin during formation of visual pathways in embryonic zebrafish.

\section{$\mathrm{N}$-cadherin has already been implicated in the development of the retinofugal projections}

The pathfinding and synaptogenesis of vertebrate retinal ganglion cell axons likely require the combined actions of many molecules, including components of the extracelluIar matrix and cell adhesion molecules (F raser et al., 1984, 1988; Neugebauer et al., 1988; Lilienbaum et al., 1995). Another member of the cadherin superfamily, N-cadherin, was detected in the developing chicken retina and optic nerve, and outgrowth of retinal axons was stimulated by an N-cadherin substrate(Matsunaga et al., 1988a,b; Redies and Takeichi, 1993; I noue and Sanes, 1997). Furthermore, $\mathrm{N}$-cadherin is required for retinotectal synaptic formation and stabilization (Inoue and Sanes, 1997). N-cadherinexpressing retinal axons can also use R-cadherin as a substrate for axon elongation in vitro, suggesting that retinal axon migration in vivo may involve the interaction of these two cadherin molecules (Redies and Takeichi, 1993). The function of $\mathrm{N}$-cadherin in the development of retinofugal projections has also been assayed in Xenopus by injecting antibodies against $\mathrm{N}$-cadherin into the optic pathway (Stone and Sakaguchi, 1996) and by expression of a dominant negative N-cadherin mutant (Riehl et al., 1996). The former treatment affected the accuracy of retinofugal projections, whereas the latter resulted in a substantial reduction in the outgrowth of retinal ganglion cell axons. All the above findings suggest that $\mathrm{N}$-cadherin plays an important role in the initiation, extension, pathfinding, and synaptogenesis of retinal ganglion cell axons in other species.

Zebrafish $\mathrm{N}$-cadherin is present in the brain and retina of younger (15-36 hpf; Bitzur et al., 1994) and older (50 hpf) embryos (Liu et al., 1999; Liu and Raymond, unpublished observations). Our preliminary data combining in situ hybridization and immunocytochemistry with a polyclonal antibody directed against a zebrafish $\mathrm{N}$-cadherin fusion protein showed that zebrafish $\mathrm{N}$-cadherin was present on most retinal ganglion cells and on their axons; it was also found throughout the CNS, and the levels of $\mathrm{N}$-cadherin decreased substantially as the animal developed (Raymond, Barthel, Liu, unpublished observations). Although $\mathrm{N}$-cadherin has been implicated in retinal axon elongation and retinotectal synapse formation in other species (see above), and it may perform similar functions in zebrafish, its distribution in zebrafish CNS is too widespread to serve as a specific molecular marker for migrating retinal axons. In contrast, R-cadherin message is expressed by retinal ganglion cells and by R-cadherinpositive cell clusters that are strategically located along the optic pathway during critical periods of retinal axon outgrowth. Becausemany ganglion cells express R-cadherin (Liu et al., 1999) and most express N-cadherin, it is certain that some ganglion cells express both $\mathrm{N}$ - and R-cadherin. Because cadherins are able to form both homophilic and heterophilic adhesive associations, specificity of axon pathfinding and synaptogenesis in the CNS may involve combinational patterns of expression of members of the cadherin superfamily (Redies and Takeichi, 1996; Colman, 1997). Our data are consistent with a combinational role for both
$\mathrm{N}$ - and R-cadherin in the development of visual projections in zebrafish.

In chicken, two other cadherin molecules (cadherin-6B and cadherin-7) have recently been shown to be present in both a subset of retinal ganglion cells and their brain targets (Wohrn et al., 1998). A subset of ganglion cells that express both cadherin molecules project to one of the main constituents of the accessory optic system in chicken, the nucleus of the basal optic root, which also exhibits strong immunoreactivity to both cadherin-6B and cadherin-7 antibodies. Cadherin-6B and cadherin-7 were shown to bind homophilically and heterophilically (Nakagawa and Takeichi, 1995). These results led the authors to suggest that the combined action of these two cadherins may be involved in the formation and functional specificity of this visual circuit (Wohrn et al., 1998).

Both $\mathrm{N}$ - and R-cadherin mol ecules have been implicated in the regionalization and development of functionally separate neuronal circuits in the central nervous system in Xenopus, chicken, and mouse (Takeichi et al., 1990; Redies et al., 1992, 1993; Matsunami and Takeichi, 1995; Stone and Sakaguchi, 1996). To our knowledge, only one previous study has addressed this issue in fish. A novel cadherin, called ventral neural cadherin (VN-cadherin), was isolated from the neural tube of zebrafish embryos at the 15-somite stage (Franklin and Sargent, 1996). Spatial and temporal expression patterns of VN-cadherin in the zebrafish embryo suggested that it may be involved in the formation and subsequent differentiation of the central nervous system, in general, and pathfinding of the medial longitudinal fasciculus and the ventral longitudinal fasciculus, in particular (Franklin and Sargent, 1996). The present study provides additional evidence that another cadherin molecule (R-cadherin) may mediate the formation of a specific neuronal circuits (i.e., retinofugal projections) in developing zebrafish central nervous system.

\section{A different role for $\mathbf{R}$-cadherin in the optic tectum}

In our companion report (Liu et al., 1999), we noted a spatiotemporal correlation between the ingrowth of retinal ganglion axons into the optic tectum (Stuermer, 1988; Burrill and Easter, 1994) and onset of R-cadherin message in tectal cells. The present study showed that Dil-labeled retinal axons and R-cadherin-positive tectal cells were both located in the anterior and lateral regions of the optic tectum at 52-54 hpf. The earliest Dil-label ed retinal axons were located in close proximity to cells expressing R-cadherin message in tectal regions immediately adjacent to R1. However, in tectal regions more distal to R1, but still within the anterolateral optic tectum, a close relationship between R-cadherin-positive cells and Dillabeled retinal axons was not always observed. In some areas, for example, no tectal cells that expressed R-cadherin were in the vicinity of retinal axons, although tectal neurons in deeper layers expressed R-cadherin message. However, preliminary observations (Lui, Marrs and Raymond, unpublished observations) suggest that R-cadherin protein is abundant in the developing tectal synaptic layers. The somata of tectal neurons in deeper tectal layers extend long apical dendrites to superficial areas where retinal axons terminate. Because the in situ hybridization method only visual izes message in the cell body, R-cadherinmediated adhesive interactions that take place on neuro- 
nal processes at some distance from the cell body cannot be visualized using these methods.

It is also possible that R-cadherin is not involved in axonal guidance within the optic tectum, and other guidance cues which providespecific information about anteriorposterior and dorsal-ventral polarity are required to mediate retinotopic projections. For example, expression of the homeobox gene, Engrailed, in the optic tectum correlates with the topographic projection of retinal axons (reviewed by Retaux and Harris, 1996), and ectopic expression of this gene affects the accuracy of the retinotectal projections (Friedman and O'Leary, 1996; Logan et al., 1996). Engrailed effects appear to be mediated by several surface molecules, including Eph-related receptor tyrosine kinases (Logan et al., 1996; Drescher, 1997; Shigetani et al., 1997).

Nevertheless, the cl ose correlation between the devel opmental profile of R-cadherin expression in the optic tectum and the development of the retinotectal projection argues for theidea that R-cadherin may beinvolved in the process of synaptic formation similar to what has been demonstrated for N-cadherin in chicken (I noue and Sanes, 1997). In zebrafish, $\mathrm{N}$-cadherin expression levels (both message and protein) in the optic tectum are very low between 50 and $80 \mathrm{hpf}$ (Liu and Raymond, unpublished observations) when retinal axons are covering the tectal lobes (Stuermer, 1988; Burrill and Easter, 1994), whereas R-cadherin message levels increase significantly during the same period (Liu et al., 1999), as does the level of immunoreactivity with R-cadherin antibodies (Liu, Marrs and Raymond, unpublished observations). Therefore, it is plausible that adhesive interactions mediated by both $\mathrm{R}$ - and $\mathrm{N}$-cadherin are important for the formation and stabilization of retinotectal synapses in zebrafish.

It is not yet understood how cadherin can mediate both the much weaker and transient adhesion between migrating retinal axons and their substrates as well as the much tighter and more stable bonds required at synapses. Colman (1997) has suggested at least two possi ble explanations. First, there is evidence that cadherin molecules exist in a cell membrane either as monomers or strand dimers (with the cadherin molecules joined in cis). Colman proposes that strong adhesive interactions responsible for synaptic formation are mediated by cadherins that assume the strand dimeric configuration and form what is known as an "adhesion zipper," whereas the weaker adhesion between migrating axons and their substrates is mediated by adhesive interactions between monomeric cadherin proteins on adjacent cell membranes (Colman, 1997). High-resolution images of cadherin-mediated junctional specializations, such as synapses in the nervous system and adherens junctions in epithelial tissues, suggest a highly structured, ordered array (Ichimura and Hashimoto, 1988) which would be predicted by the adhesion zipper. The model proposed by Colman (1997) is therefore consistent with a multifunctional role for R-cadherin in both axonal outgrowth and synaptogenesis.

\section{CONCLUSIONS}

We have documented a close spatial relationship between outgrowing retinal ganglion cell axons and cells expressing zebrafish R-cadherin in the hypothalamus and the pretectum, suggesting that R-cadherin is involved in the pathfinding and synaptogenesis of retinal axons in zebrafish. Once retinal axons have arrived at the optic tectum, more specific guidance cues are thought to be important in the formation of retinotopic projections, although $\mathrm{R}$-cadherin along with $\mathrm{N}$-cadherin may be involved in stabilization of synapses. Future experiments will attempt to perturb the function of $\mathrm{N}$-cadherin and R-cadherin, in order to assess their roles in pathfinding of retinal axons and formation of synaptic connections in zebrafish.

\section{ACKNOWLEDGMENTS}

Wethank Dr. Stephen S. Easter for hel pful comments on the manuscript, and we thank Linda Barthel for expert technical assistance. Drs. J ames Hurley and Bruce Appel kindly provided cDNA libraries, and Dr. Benjamin Geiger provided a cDNA clone of zebrafish $\mathrm{N}$-cadherin. This research was supported by $\mathrm{NIH}$ grants EY11365 (J .A. Marrs), EY04318 (P.A. Raymond), and NRSA EY06892 (Q. Liu).

\section{LITERATURE CITED}

Arndt K, Redies C. 1996. Restricted expression of R-cadherin by brain nuclei and neural circuits of the developing chicken brain. J Comp Neurol 373:373-399.

Barthel LK, Raymond PA. 1990. I mproved method for obtaining 3- $\mu \mathrm{m}$ cryosections for immunocytochemistry. J Histochem Cytochem 9:13831388.

Bastmeyer M, Ott H, Leppert CA, Stuermer CAO. 1995. Fish E587 glycoprotein, a member of the LI family of cell adhesion molecules, participates in axonal fasciculation and the age-related order of ganglion cell axons in the goldfish retina. J Cell Biol 130:969-976.

Bitzur S, Kam Z, Geiger B. 1994. Structure and distribution of N-cadherin in developing zebrafish embryos: morphogenetic effects of ectopic over-expression. Dev Dyn 201:121-136.

Bixby J L, Zhang R. 1990. Purified N-cadherin is a potent substrate for the rapid induction of neurite outgrowth. J Cell Biol 110:1253-1260.

Bixby J L, Harris WA. 1991. Molecular mechanisms of axon growth and guidance. Annu Rev Cell Biol 7:117-159.

Bonhoeffer F, Gierer A. 1984. How do retinal axons find their targets on the tectum? Trends Neurosci 7:378-381.

Brümmendorf T, Hubert $\mathrm{M}$, Treubert $\mathrm{U}$, Leuscher $\mathrm{R}$, Tarnok A, Rathjen FG. 1993. The axonal recognition molecule $F 11$ is a multifunctional protein specific domains mediate interactions with $\mathrm{Ng}$-CAM and restrictin. Neuron 10:1-20.

Burrill J D, Easter SS, J r. 1994. Development of the retinofugal projections in the embryonic and larval zebrafish (Brachydanio rerio). J Comp Neurol 346:583-600.

Burrill J D, Easter SS, J r. 1995. The first retinal axons and their microenvironment in zebrafish: cryptic pioneers and the pretract. J Neurosci 15:2935-2947.

Chitnis AB, Kuwada J Y. 1990. Axogenesis in the brain of zebrafish embryos. J Neurosci 10:1892-1905.

Colman DR. 1997. Neurites, synapses, and cadherin reconciled. Mol Cell Neurosci 10:1-6.

Cooke J E, Xu QL, Wilson SW, Holder N. 1997. Characterization of fivenovel zebrafish Eph-related receptor tyrosine kinases suggests roles in patterning the neural plate. Dev Genes Evol 206:515-531.

Dodd J , J essell TM. 1988. Axon guidance and the patterning of neuronal projections in vertebrates. Science 242:692-699.

Drazba J , Lemmon V. 1990. The role of cell adhesion molecules in neurite outgrowth on Müller cells. Dev Biol 138:82-93.

Drescher U, Bonhoeffer F, Müller BK. 1997. The E ph family in retinal axon guidance. Curr Opin Neurobiol 7:75-80.

Fannon AM, Colman DR. 1996. A model for central synaptic junctional complex formation based on the differential adhesive specificities of the cadherins Neuron 17:423-434.

Franklin J L, Sargent TD. 1996. Ventral neural cadherin, a novel cadherin expressed in a subset of neural tissues in the zebrafish embryo. Dev Dyn 206:121-130. 
Fraser SE, Murray BA, Chuong CM, Edelman GM. 1984. Alteration of the retinotectal map in Xenopus by antibodies to neural cell adhesion molecules. Proc Natl Acad Sci USA 81:4222-4226

Fraser SE, Charhart MS, Murray BA, Chuong CM, Edelman GM. 1988. Alterations in the Xenopus N-CAM. Dev Biol 129:217-230.

Friedman GC, O'Leary DDM. 1996. Retroviral misexpression of engrailed genes in the chick optic tectum perturbs the topographic targeting of retinal axons. J Neurosci 16:5498-5509.

Fujisawa H, Tani N, Watanabe K, I bata Y. 1982. Branching of regenerating retinal axons and preferential selection of appropriate branches for specific neuronal connections in the newt. Dev Biol 90:43-57.

Hutton J C, Christofori G, Chi WY, Edman U, Guest PC, Hanahan D, Kelly RB. 1993. Molecular cloning of mouse pancreatic islet R-cadherin: differential expression in endocrineand exocrinetissue. Mol Endocrinol 7:1151-1160.

Ichimura T, Hashimoto PH. 1988. Structural components in the synaptic cleft captured by freeze-substitution and deep etching of directly frozen cerebellar cortex. J Neurocytol 17:3-12.

Inoue A, Sanes J R. 1997. Lamina-specific connectivity in the brain: regulation by $\mathrm{N}$-cadherin, neurotrophins, and glycoconjugates. Science 276:1428-1431.

Inuzuka H, Miyatani S, Takeichi M. 1991. R-cadherin: a novel $\mathrm{Ca}^{2+}$ dependent cell-cell adhesion molecule expressed in the retina. Neuron 7:69-79.

J owett T, Mancera M, Amores A, Yan YL. 1996. In situ hybridization to embryo whole mounts and tissue sections: mRNA detection and application to developmental studies. In: Clark M, editor. In situ hybridization. London; New York: Chapman and Hall. p. 91-121.

Lilienbaum A, Reszka AA, Horwitz AF, Holt CE. 1995. Chimeric integrins expressed in retinal ganglion cells impair process outgrowth in vivo. Mol Cell Neurosci 6:139-152.

Liu Q, Sanborn KL, Cobb N, Raymond PA, Marrs J A. 1999. R-cadherin expression in the developing and adult zebrafish visual system. J Comp Neurol 410:303-319.

Logan C, Wizenmann A, Drescher U, Monschau B, Bonhoeffer F, Lumsden A. 1996. Rostral optic tectum acquires caudal characteristics following ectopic Engrailed expression. Curr Biol 6:1006-1014.

Matsunaga M, Hatta K, Takeichi M. 1988a. Role of N-cadherin cell adhesion molecules in the histogenesis of neural retina. Neuron 1 : 289-95.

Matsunaga M, Hatta K, Nagafuchi A, Takeichi M. 1988b. Guidance of optic nerve fibers by $\mathrm{N}$-cadherin adhesion molecules. Nature 334:62-64.

Matsunami H, Miyatani S, Inoue T, Copeland NG, Gilbert DJ . 1993. Cell binding specificity of mouse R-cadherin and chromosomal mapping of the gene. J Cell Sci 106:401-409.

Matsunami H, Takeichi M. 1995. Fetal brain subdivisions defined by R- and $\mathrm{E}$-cadherin expressions: evidence for the role of cadherin activity in region-specific, cell-cell adhesion. Dev Biol 172:466-478.

Nakagawa S, Takeichi M. 1995. Neural crest cell-cell adhesion controlled by sequential and subpopulation-specific expression of novel cadherins. Development 121:1321-1332.

Neugebauer KM, Tomaselli KJ , Lilien J , Reichardt LF. 1988. N-cadherin, NCAM, and integrins promote retinal outgrowth on astrocytes in vitro. J Cell Biol 107:1177-1187.

O'Rourke NA, Fraser SE. 1990. Dynamic changes in optic fiber terminal arbors lead to retinotopic map formation: an in vivo confocal microscopic study. Neuron 5:159-171.

Paradies NE, Grunwald GB. 1993. Purification and characterization of NCAD90, a soluble endogenous form of N-cadherin, which is generated by proteolysis during retinal development and retains adhesive and neurite-promoting function. J Neurosci Res 36:33-45.

Puelles L, Amat J A, Martinez de la Torre M. 1987. Segment-related mosaic neurogenetic pattern in the forebrain and mesencephal on of early chick embryos: I. Topography of AchE-positive neuroblasts up to stage $\mathrm{HH} 18$. J Comp Neurol 266:247-268.

Redies C. 1995. Cadherin expression in the developing vertebrate CNS: from neuromeres to brain nuclei and neural circuits. Exp Cell Res 220:243-256.

Redies C. 1997. Cadherins and the formation of neural circuitry in the vertebrate CNS. Cell Tissue Res 290:405-413.

Redies C, Takeichi M. 1993. N-and R-cadherin expression in theoptic nerve of the chicken embryo. Glia 8:161-171.

Redies C, Takeichi M. 1996. Cadherins in the developing central nervous system: an adhesive code for segmental and functional subdivisions. Dev Biol 180:413-423.
Redies C, Inuzuka H, Takeichi M. 1992. Restricted expression of N- and R-cadherin on neurites of the developing chicken CNS. J Neurosci 12:3525-3534.

Redies C, Engelhart K, Takeichi M. 1993. Differential expression of N-and R-cadherin in functional neuronal systems and other structures of the developing chicken brain. J Comp Neurol 333:398-416.

Retaux S, Harris WA. 1996. Engrailed and retinotectal topography. Trends Neurosci 19:542-546.

Riehl R, J ohnson K, Bradley R, Grunwald GB, Cornel E, LilienbaumA, Holt CE. 1996. Cadherin function is required for axon outgrowth in retinal ganglion cells in vivo. Neuron 17:837-848.

Ross LS, Parrett T, Easter SS, J r. 1992. Axonogenesis and morphogenesis in the embryonic zebrafish brain. J Neurosci 12:467-482.

Shigetani Y, Funahashi J , Nakamura H. 1997. En-2 regulates the expression of the ligands for Eph-type tyrosine kinases in chick embryonic tectum. Neurosci Res 27:211-217.

Sperry RW. 1963. Chemoaffinity in the orderly growth of nerve fiber patterns and connections. Proc Natl Acad Sci USA 50:703-710.

Singleton CD, Casagrande VA. 1996. A reliable and sensitive method for fluorescent photoconversion. J Neurosci Methods 64:47-54.

Stoeckli E, Landmesser LT. 1995. Axonin-1, Nr-CAM and Ng-CAM play different roles in the in vivo guidance of chick commissural neurons. Neuron 14:1165-1179.

Stone KE, Sakaguchi DS. 1996. Perturbation of the developing Xenopus retinotectal projection following injections of antibodies against $\beta_{1}$ integrin receptors and N-cadherin. Dev Biol 180:297-310.

Stuermer CAO. 1988. Retinotopic organization of the developing retinotectal projection in the zebrafish embryo.J Neurosci 8:4513-4530.

Takeichi M. 1990. Cadherins: a molecular family important in selective cell-cell adhesion. Ann Rev Biochem 59:237-52.

Takeichi M. 1995. Morphogenetic roles of classic cadherins. Curr Opin Cell Biol 7:619-627.

Takeichi M, Inuzuka H, Shimamura K, Fujimori T, Nagafuchi A. 1990 Cadherin subclasses: differential expression and their roles in neural morphogenesis. Cold Spring Harbor Symposia on Quantitative Biol 55:319-325.

Tanihara H, Sano K, Heimark RL, St J ohn T, Suzuki S. 1994. Cloning of five human cadherins clarifies characteristic features of cadherin extracellular domain and provides further evidence for two structurally different types of cadherin. Cell Adh Comm 2:15-26.

Tomaselli KJ, Neugebauer KN, Bixby J L, Lilien J, Reichardt LF. 1988. $\mathrm{N}$-cadherin and integrins: two receptor systems that mediate neurite outgrowth on astrocyte surfaces. Neuron 1:33-43.

Trisler D, Collins F. 1987. Corresponding spatial gradients of TOP molecules in the developing retina and optic tectum. Science 237:12081209.

Uchida N, Honjo Y, J ohnson KR, Wheelock MJ, Takeichi M. 1996. The catenin/cadherin adhesion system is localized in synaptic junctions bordering transmitter releasezones. J Cell Biol 135:767-779.

von Bartheld CS, Cunningham DE, Rubel EW. 1990. Neuronal tracing with Dil: decalcification, cryosectioning, and photoconversion for light and el ectron microscopic analysis. J Histochem Cytochem 38:725-733.

Walter J , Kern-Veits B, Huf J , Stolze B, Bonhoeffer F. 1987. Recognition of position-specific properties of tectal cell membranes by retinal axons in vitro. Development 101:685-696.

Westerfield M. 1996. The zebrafish book. Eugene, OR: University of Oregon Press.

Williams EJ , Furness J , Walsh FS, Doherty P. 1994. Activation of the EGF receptor underlies neurite outgrowth stimulated by L1, N-CAM, and $\mathrm{N}$-cadherin. Neuron 13:583-594.

Wilson SW, Ross LS, Parrett T, Easter SS, J r. 1990. The development of a simple scaffold of axon tracts in the brain of the embryonic zebrafish, Brachydanio rerio. Development 108:121-145.

Wohrn J CP, Puelles L, Nakagawa S, Takeichi M, Redies C. 1998. Cadherin expression in the retina and retinofugal pathways of the chicken embryos. J Comp Neurol 396:20-38.

Xu QL, Alldus G, Macdonald R, Wilkinson DG, Holder N. 1996. Function of the Eph-related kinase rtk1 in patterning of the zebrafish forebrain. Nature 381:319-322.

Yamagata M, Herman J P, Sanes J R. 1995. Lamina-specific expression of adhesion molecules in developing chick optic tectum. J Neurosci $15: 4556-4571$ 